\title{
MOTIVASI KERJA DAN PENGARUHNYA TERHADAP KINERJA ISLAM KARYAWAN BRISYARIAH KCI SURABAYA GUBENG
}

\author{
Wednesdayanti Angelia Putri \\ Mahasiswa Program Studi S-1 Ekonomi Islam - Fakultas Ekonomi dan Bisnis - Universitas \\ Airlangga \\ Email: wenny.putri92@gmail.com
}

Ari Prasetyo

Departemen Ekonomi Syariah - Fakultas Ekonomi dan Bisnis - Universitas Airlangga

Ari_feunair@yahoo.co.id

\begin{abstract}
Basically BRISyariah's employee have different job motivations. Working on an Islamic environment certainly at least a little or a lot will affected their job motives, so that finnaly, it can be shown the Islamic performance employee. The aim of this research was to examine job motivation of BRISyariah KCl Surabaya Gubeng's employee influance on their Islamic performance whether the Islamic performance assessment was affected by their motivations.

This research is quantitative research and uses linier regression analysis as analysis model. The sample in this research was obtained by purposive sampling method. Based on this method, there were 44 employees in accordance with the criteria of this research's sample that was determined with a minimum work term of 3 months. The performance assessment was rated by each department manager where they were placed. Data collected by distributing questionnaires about their job motivation to employees and performance appraisal sheet to the manager.

The results of the research indicate that job motivation influence on the Islamic performance of BRISyariah KCI Surabaya Gubeng's employee.
\end{abstract}

\section{Keywords: Job Motivation, Islamic Performance Employee}

\section{PENDAHULUAN}

\section{Latar Belakang}

Bekerja bagi manusia sebagai sumber daya Islam merupakan kewajiban yang harus dilakukan dengan tujuan mencari nafkah demi memenuhi kebutuhan hidupnya. Pada dasarnya Allah telah menetapkan bahwa manusia berperan sebagai khalifah. Karim (2008:102-103) menyatakan bahwa tanggung jawab manusia sebagai khalifah adalah mengelola resources yang telah disediakan oleh Allah secara efisien dan optimal agar kesejahteraan dan keadilan dapat ditegakkan.

"Human capital merupakan faktor manusia dalam organisasi: mencakup intelegensi, keterampilan, dan keahlian manusia yang memberikan karakter khas pada organisasi" (Thoha dan Hutapea dalam Arcynthia, 2013). Berdasarkan sensus penduduk tahun 2010 jumlah penduduk Indonesia mencapai angka 237.641.326 jiwa (www.bps.go.id). Tahun 2013 jumlah penduduk Indonesia diperkirakan mencapai 250 juta jiwa dengan tingkat pertumbuhan penduduk 
$1,49 \%$ per tahun. Dari jumlah tersebut sebesar $63,54 \%$ bagian terdiri atas angkatan kerja (www.bkkbn.go.id).

Kompetisi dalam dunia kerja pada era globalisasi saat ini semakin mengglobal artinya tidak hanya fokus pada persaingan antar perusahaan di dalam negeri saja melainkan telah menuntut kompetisi skala internasional. Hal ini kemudian menyebabkan organisasi atau perusahaan harus melakukan langkah inovasi dan perubahan cara pandang dari tradisional menjadi modern.

Menghadapi kondisi tersebut harus dipersiapkan dengan matang terutama pada pemberdayaan faktor-faktor sumber daya manusia yang bermutu dan memiliki kualitas tepat. Mayoritas perusahaan-perusahaan dalam segala ukuran saat ini menginginkan SDM yang berkualitas baik.

Sumber daya manusia sebagai aset perusahaan terbesar harus dapat ditingkatkan kualitas kerjanya sehingga tujuan penggunaannya dapat optimal. Kualitas kerja merupakan salah satu indikator yang mempengaruhi kinerja. Menurut Siagian (Tjahjono dan Gunarsih, 2006:68), "Indikator yang mempengaruhi kinerja karyawan meliputi; kualitas kerja, kuantitas kerja, pengetahuan, keandalan, dan kehadiran".

Tenaga kerja di Indonesia sebagian besar berpendidikan rendah dengan keahlian dan keterampilan yang masih minim. Pemahaman yang kurang terhadap ilmu pengetahuan dan teknologi menyebabkan produktivitas rendah dan perusahaan sulit untuk bersaing dengan perusahaan atau negara lain. Selain faktor tersebut, kurangnya motivasi dalam bekerja yang dimiliki oleh tenaga kerja juga akan mempengaruhi hasil kinerjanya.

Karyawan yang memiliki motivasi tinggi akan berusaha mengoptimalkan kemampuannya dalam menyelesaikan pekerjaannya dengan baik. Sedangkan karyawan dengan motivasi kerja yang kurang cenderung menunjukkan sifat malas dalam bekerja sehingga berdampak pada hasil kerja yang buruk.

Teori motivasi dalam organisasi menurut Robert Kreitner dan Angelo Kinicki (Wibowo, 2013: 378) mengatakan bahwa motivasi merupakan proses psikologis yang menyebabkan timbulnya perilaku dan mengarahkannya pada pencapaian tujuan atau gool-directed behavior. Perlunya memenuhi kebutuhan memunculkan motivasi seseorang untuk melakukan pekerjaan. Motivasi kerja dalam Islam berkaitan dengan fungsi dan kedudukan bekerja. Bekerja merupakan sebuah kewajiban dalam Islam bagi umatnya untuk memenuhi kebutuhan hidup. Motivasi kerja dalam Islam adalah untuk mencari nafkah dan merupakan bagian dari ibadah.

Berdasarkan penjelasan di atas dapat dikatakan bahwa motivasi kerja merupakan hal penting dalam suatu organisasi yang berperan sebagai penggerak seseorang untuk mencapai tujuan atau sasaran yang diinginkan. Motivasi kerja karyawan perlu mendapat 
perhatian lebih bagi manajer atau supervisor dalam memberdayakan karyawannya agar lebih semangat dalam bekerja sehingga mampu memberikan hasil kinerja yang baik.

Oleh karena itu dalam penelitian ini ingin mengetahui apakah motivasi kerja dapat berpengaruh secara signifikan terhadap penilaian kinerja Islam karyawan. Subjek penelitian dipilih adalah karyawan pada objek yaitu salah satu bank Syariah ternama di Indonesia, Bank BRISyariah $\mathrm{KCl}$ Surabaya Gubeng. Berdasarkan uraian di atas, maka rumusan masalah dalam penelitian ini adalah: apakah motivasi kerja berpengaruh secara terhadap kinerja Islam karyawan pada BRISyariah KCI Surabaya Gubeng?

\section{LANDASAN TEORI DAN PENGEMBANGAN HIPOTESIS \\ Motivasi Kerja}

Motivasi didefinisikan sebagai proses pemberian energi pada perilaku seseorang. Memberikan motivasi atau daya perangsang kepada karyawan merupakan upaya penting perusahaan dalam rangka meningkatkan produktivitas kerja dan menjaga etos kerja karyawan agar tetap giat dalam bekerja. Pada gilirannya, karyawan yang terdorong gairah bekerjanya akan siap menerima tanggung jawab pekerjaan yang diberikan atasan dengan semangat tinggi.

Menurut Stephen P. Robbins (Wibowo, 2013:378), motivasi merupakan proses yang menimbulkan adanya intensitas (intensity), arah (direction), dan usaha terus-menerus (persistence) yang dilakukan oleh individu menuju pencapaian tujuan.

Adanya kebutuhan yang harus dipenuhi menjadi faktor pendorong penting yang menyebabkan manusia bekerja. Tujuan atau sasaran yang hendak dicapai tersebut terbagi menjadi kebutuhan pribadi dan organisasi. Pemenuhan kebutuhan pribadi manusia yaitu dengan melakukan pekerjaan untuk mengharapkan kompensasi mendapatkan imbalan, upah atau gaji dari hasil kerjanya.

Teori motivasi yang diungkapkan Abraham Maslow diklasifikasikan ke dalam lima tingkatan hierarki kebutuhan, dari yang paling dasar hingga yang paling puncak yaitu: kebutuhan fisiologis (physiological), kebutuhan rasa aman (safety), kebutuhan sosial (affiliation), kebutuhan pengakuan atau penghargaan (esteem), dan aktualisasi diri (self actualization). Inti dari teori ini adalah bahwa kebutuhan yang paling dasar yaitu kebutuhan fisiologis harus dipenuhi terlebih dahulu sebelum memuaskan kebutuhan di tingkat yang lebih atas.

Teori kedua adalah Mc. Clelland's achievement Motivation Theory oleh David Mc. Clelland. Dalam teori yang dikenal juga sebagai teori motivasi prestasi ini kebutuhan manusia diklasifikasikan menjadi tiga, yang pertama adalah Need for Achievement yaitu kebutuhan dalam mencapai kesuksesan, yaitu kemampuan 
untuk mencapai hubungan kepada standar perusahaan yang telah ditentukan juga perjuangan karyawan untuk menuju keberhasilan. Kedua, Need for Affiliation adalah kebutuhan untuk berafiliasi, yaitu hasrat untuk bersahabat dan mengenal lebih dekat rekan kerja atau para karyawan di dalam organisasi dan yang terakhir adalah Need for Power yang merupakan kebutuhan akan kekuasaan atau otoritas kerja, yaitu kebutuhan untuk membuat orang berperilaku dalam keadaan yang wajar dan bijaksana di dalam tugasnya masingmasing.

Existence, Relatedness And Growth (ERG) Theory merupakan teori yang dikemukakan oleh Alderfer. Alderfer menyederhanakan dari lima kebutuhan dalam hierarki Maslow menjadi tiga kebutuhan saja yang harus dipenuhi oleh manusia yaitu Existence (Keberadaan atau Eksistensi), Relatedness (Keterhubungan), Growth (Pertumbuhan).

\section{Motivasi Kerja Islam}

\begin{tabular}{lll}
\multicolumn{2}{c}{ Motivasi } & \multicolumn{1}{c}{ dapat didefinisikan } \\
sebagai suatu energi di dalam diri \\
seseorang & yang & mendorong,
\end{tabular}
membangkitkan, mengarahkan, dan menjaga perilaku mereka untuk mencapai tujuan tertentu ang dikehendaki. Allah SWT memerintahkan dalam surat Al-Baqarah ayat 148 kepada hamba-Nya untuk selalu berlomba dalam hal kebajikan.

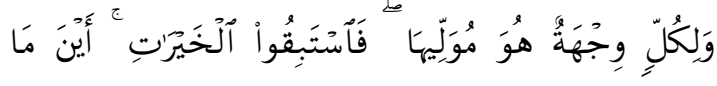

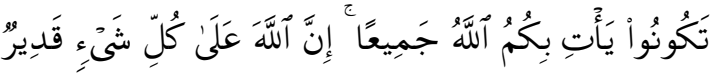

Walikullin-wijhatun huwa muwallihā fastabiqul-khairāti aina mā takunu ya'ti bikumullāhu jamî'an innallāha 'alā kulli syai-in qadir.

Artinya: "Dan bagi tiap-tiap umat ada kiblatnya (sendiri) yang ia menghadap kepadanya. Maka berlomba-lombalah (dalam membuat) kebaikan. di mana saja kamu berada pasti Allah akan mengumpulkan kamu sekalian (pada hari kiamat). Sesungguhnya Allah Maha Kuasa atas segala sesuatu". (QS. AlBaqarah: 148) (Depag Rl, 2002:24).

Islamic human capital menjelaskan bahwa Islam memandang penting motivasi dalam bekerja. Faktor pendorong yang menyebabkan manusia harus bekerja adalah adanya kebutuhan dan tujuan yang harus dipenuhi. Islam menuntut manusia bekerja dalam rangka memenuhi kebutuhan sehingga memperoleh manfaat dan kebaikan bagi kehidupannya. Hal ini merupakan objectives atau sasaran dari hukum Islam yaitu maslahat (kesejahteraan).

Sasaran pemenuhan kebutuhan manusia dibagi menjadi tiga tingkatan kategori yaitu essentials (al-dharûriyat), exigencies (al-hâjiyyât), dan embellishments (al-tahsiniyyât). Imam AlShatibi (Al-Raysuni, 2006:108-109) menjelaskan klasifikasi atas ketiganya sebagai berikut: 
1. Essentials (al-dharûriyat)

Al-dharûriyat disebut juga dengan kebutuhan tingkat primer atau utama. Dalam Islam disebutkan lima tujuan maqasid syariah yang harus ada pada manusia untuk diupayakan keberadaan dan kesempurnaannya adalah; agama, jiwa, akal, harta, dan keturunan. Kelima perkara ini penting untuk mendukung perilaku dalam kehidupan sesuai ajaran Islam sehingga Allah memerintahkan segala upaya perbuatan untuk memenuhi dan menjaganya. Allah juga melarang segala hal yang dapat mengakibatkan hilang atau berkurangnya lima dharûriyat tersebut. Prioritas kebutuhan dharûriyat harus segera dipenuhi agar tidak membahayakan eksistensi manusia. Contoh dari kebutuhan ini adalah kebutuhan sandang, pangan, dan papan. 2. Exigencies (al-hâjiyyât)

Al-hâjiyyât merupakan kebutuhan tingkat sekunder. Kebutuhan ini dalam pemenuhannya menempati posisi sebagai pelengkap bagi kehidupan manusia. Apabila kebutuhan hâjiyyât tidak terpenuhi, maka tidak akan mengancam kelangsungan hidup manusia. Pemenuhan hâjiyyât merupakan upaya dalam melindungi kebutuhan dharûriyat. Makan dengan porsi yang cukup dan pemenuhan kualitas gizi yang lengkap merupakan salah satu contoh pemenuhan kebutuan hâjiyyât.

3. Embellishment (al-tahsiniyyât)

$$
\text { Kebutuhan }
$$

Al-tahsiniyyât merupakan kebutuhan di tingkat tertier. Kebutuhan tertier sebaiknya dipenuhi untuk memperindah kehidupan. Tujuan kebutuhan tahsiniyyat tidak menimbulkan kewajiban dalam memenuhinya karena tidak akan mengancam kelangsungan hidup dan tidak menimbulkan penderitaan apabila tidak dipenuhi. Prioritas pada tingkat tertier ini apabila dipenuhi akan meningkatkan kepuasan atau kenikmatan. Menu makan dan minum sesuai selera yang diinginkan merupakan salah satu bentuk kebutuhan tertier.

Motivasi kerja dalam Islam adalah mencari nafkah dan merupakan bagian dari ibadah. Rivai (2009:872-875), menjelaskan konsep motivasi kerja dalam perspektif Islam adalah motivasi kerja yang bersifat positif. Motivasi kerja yang bersifat positif berawal dari perintah Allah terhadap manusia untuk senantiasa melakukan kebajikan. Motivasi kerja yang bersifat positif dirumuskan oleh Rivai dalam tiga nilai pokok yaitu (2009:872-875):

1. Penghargaan terhadap pekerjaan

Penghargaan terhadap pekerjaan yang dimaksud oleh Rivai adalah penghargaan Allah SWT atas pekerjaan yang diselesaikan dengan baik oleh hambanya dan penghargaan seorang pimpinan kepada hasil kerja karyawannya. Seorang karyawan yang dapat mensyukuri nikmat yang diberikan kepadanya berupa pekerjaan, dia akan senantiasa menjalankan pekerjaannya sesuai dengan aturan yang ditentukan perusahaan di tempat dia bekerja. Demikian juga Allah SWT menyukai orang 
yang senantiasa bersyukur atas karunia yang diberikan kepadanya.

Selain itu, pengakuan dan penghargaan pimpinan atas pekerjaan yang diselesaikan dengan baik oleh karyawan akan meyenangkan perasaan karyawan tersebut. Pimpinan dapat memberikan penghargaan berupa pujian atau feedback insentif lain kepada karyawan yang berhasil menyelesaikan pekerjaan dengan baik dan sesuai target serta standar yang ditetapkan oleh perusahaan.

2. Komunikasi dan informasi yang baik dan jelas.

Dijelaskan oleh Rivai bahwa kebanyakan orang ingin mengetahui latar belakang atau alasan suatu tindakan. Oleh karena itu pemberian informasi yang jelas, tidak boleh diabaikan oleh para pimpinan untuk menghindari adanya gosip, desas-desus, dan sebagainya. Kebutuhan pentingnya penjelasan atau informasi mengenai pekerjaan harus dikomunikasikan dengan baik, jelas dan terperinci kepada karyawan. Hasilnya, setelah mendapatkan penjelasan atau informasi yang meyakinkan, karyawan akan termotivasi dalam bekerja karena tidak akan ada rasa keraguan atau tidak akan setengah-setengah dalam bekerja.

3. Kesempatan berpartisipasi.

Partisipasi yang dimaksud oleh Rivai adalah yang digunakan sebagai 'democratic management' atau 'consultative supervision'. Dengan dijalankannya partisipasi dapat diperoleh manfaat, seperti bisa dibuatnya keputusan yang lebih baik karena banyaknya sumbangan pikiran, adanya penerimaan yang lebih besar terhadap perintah yang diberikan dan adanya perasaan diperlukan atau 'feeling of importance'.

Sehingga dapat disimpulkan bahwa motivasi kerja dalam perspektif Islam adalah serangkaian kekuatan dan nilai-nilai yang tercermin dalam Al-Qur'an dan Al-Hadits sebagai input dari suatu proses di dalam diri seseorang yang mampu mempengaruhi, mendorong, menggerakkan, dan mengarahkan. perilakunya dalam melaksanakan tanggung jawab pekerjaan dengan baik dan sebagai bentuk aktualisasi diri sebagai hamba Allah SWT yang beriman.

\section{Kinerja Islam Karyawan}

Stephen Robbins dalam Sinambela (2012:5) mengemukakan bahwa kinerja dapat diartikan sebagai hasil evaluasi terhadap pekerjaan yang dilakukan individu dibandingkan dengan kriteria yang ditetapkan bersama.

Senada dengan pendapat tersebut, Rivai dan Basri dalam Sinambela (2012:6) menambahkan bahwa kinerja adalah hasil atau tingkat keberhasilan seseorang atau keseluruhan selama periode tertentu di dalam melaksanakan tugas dibandingkan dengan berbagai kemungkinan, seperti standar hasil kerja, target atau sasaran atau kriteria yang telah ditentukan terlebih dahulu dan telah disepakati bersama. 
Menghadapi persaingan global
dan perkembangan kompetitif yang semakin pesat, perusahaan membutuhkan tenaga kerja yang berprestasi tinggi. Kinerja adalah hasil prestasi kerja karyawan yang dapat digunakan untuk mengevaluasi seberapa baik atau buruk mereka menyelesaikan pekerjaannya.

Dalam Islam, Allah pasti akan menilai semua perbuatan manusia. Allah akan menghitung usaha dan amalan umatnya yang berusaha dan beramal. Mereka akan dapat melihat bagaimana hasil usaha dan menerima balasan atas usaha dan amal yang mereka perbuat. Allah akan memberikan nasib baik dan beruntung bagi hamba-Nya yang mau bersungguh-sungguh dalam berusaha.

Hasil yang didapatkan seseorang adalah berasal dari usaha-usaha baik yang mereka lakukan dalam rangka meraih apa yang mereka mohonkan. Hal ini bukan saja merupakan hasil atas doa yang tulus saja tetapi juga kesungguhan bekerja serta kesucian akidah (Shihab, 2009:533).

Kinerja merupakan hasil dari "upaya yang sungguh-sungguh, dengan mengerahkan seluruh asset, pikir, dan zikirnya untuk mengaktualisasikan atau menampakkan arti dirinya sebagai hamba Allah yang harus menundukkan dunia dan menempatkan dirinya sebagai bagian dari masyarakat yang terbaik". (Tasmara, 2002:25)

Pahala dan kesuksesan merupakan hasil atas usaha dan kerja keras manusia dalam bekerja dengan niat mencari ridha Allah. Manusia akan diberi tahu bagaimana balasan dari usaha dan amalan tersebut. Apabila manusia melakukan dengan kebaikan maka akan dibalas dengan kebaikan. Sebaliknya apabila manusia melakukan dengan keburukan maka akan dibalas dengan keburukan pula.

$$
\text { Zadjuli dalam Muafi }
$$

berpendapat bahwa, "Islam menilai kinerja religius seseorang dengan melihat beberapa indikator antara lain: (1) niat bekerjanya karena Allah, (2) menerapkan kaidah/ norma/ syariah secara kaffah dalam bekerja, (3) motivasi bekerja adalah spiritual dengan mencari keberuntungan di dunia dan akherat, (4) menerapkan asas efisiensi dan manfaat dengan tetap menjaga kelestarian hidup, (5) menjaga keseimbangan antara mencari harta dengan beribadah, (6) bersyukur kepada Allah dengan cara tidak konsumtif, mengeluarkan ZIS, dan menyantuni anak yatim dan fakir miskin.

Dari beberapa masukan pendapat tokoh diatas mengenai pengertian kinerja dapat disimpulkan bahwa kinerja adalah hasil dari pelaksanaan kerja yang dicapai oleh karyawan sesuai dengan tanggung jawab dan deskripsi pekerjaan yang diberikan kepadanya dibandingkan dengan standaar operasional perusahaan yang sudah ditetapkan dan dikomunikasikan terlebih dahulu. Semakin tinggi kualitas dan kuantitas hasil kerjanya maka semakin tinggi pula performance atau prestasi kerjanyanya. 


\section{Kerangka Penelitian dan Hipotesis}

Penelitian ini menggunakan teori tentang motivasi kerja positif yang merupakan teori yang dikembangkan oleh Veithzal Rivai dalam kajian literaturnya yaitu "Islamic Human Capital". Dalam kajiannya, teori ini merupakan hasil sintesa atas teori-teori motivasi kerja ternama yang kemudian disesuaikan dengan kondisi-kondisi yang memenuhi perspektif Islam. Dalam penelitian ini ingin melihat pengaruh secara signifikan dari motivasi kerja terhadap kinerja Islam karyawan di BRISyariah $\mathrm{KCl}$ Surabaya Gubeng.

Muafi (2003) telah melakukan penelitian hampir serupa berjudul "Pengaruh Motivasi Spiritual Karyawan Terhadap Kinerja Religius: Studi Empiris Di Kawasan Industri Rungkut Surabaya (SIER)". Hipotesis dalam penelitian ini menyatakan bahwa: (1) ada pengaruh motivasi akidah, motivasi ibadah, dan motivasi muamalat secara bersama-sama terhadap kinerja religius, (2) motivasi muamalat memiliki pengaruh dominan terhadap kinerja religius, (3) ada perbedaan kinerja karyawan operasional dan non operasional di kawasan industri Rungkut Surabaya. Hasil penelitian menunjukkan bahwa pada hipotesis pertama menggunakan analisis regresi berganda dapat disimpulkan bahwa motivasi akidah (X1), motivasi ibadah (X2), dan motivasi muamalat (X3) berpengaruh serempak terhadap kinerja $(Y)$. Hipotesis kedua dapat disimpulkan bahwa motivasi muamalat berpengaruh secara dominan terhadap kinerja religius dimana $t$ hitung untuk motivasi akidah dan hipotesis ketiga ditolak karena tidak ada perbedaan kinerja antara karyawan operasional dan non operasional, dengan probabilitas 0,000 .

Selain itu penelitian serupa juga pernah dilakukan oleh Azizah (2013) dengan judul penelitian, "Pengaruh Motivasi Spiritual Islam Terhadap Kinerja Islam Karyawan di BRISyariah $\mathrm{KCl}$ Surabaya Gubeng", Haryo Bramantyo (2014) "Pengaruh Motivasi Kerja dan Kepuasan Kerja Terhadap Kinerja Pegawai Balai Besar Sungai Brantas Jawa Timur dengan Varibel Intervening Komitmen Organisasional", Ridhan Fadhlur R (2013) "Pengaruh Etos Kerja Islam Terhadap Kinerja Islam Karyawan dengan Variabel Moderator Motivasi Kerja Pada Bank Muamalat Di Surabaya".

Hipotesis dalam penelitian ini adalah $\mathrm{H}$ : Ada pengaruh dari motivasi kerja terhadap kinerja Islam karyawan pada BRISyariah $\mathrm{KCl}$ Surabaya Gubeng dengan model analisis yaitu:

$$
Y=\exists o+b X \text {. ei }
$$

Dimana:

$Y=$ Kinerja Islam karyawan

$\mathrm{X}=$ Motivasi kerja

$\exists \mathrm{O}=$ Konstanta

$\mathrm{b}=$ Koefisien regresi

ei $=$ Variabel error 


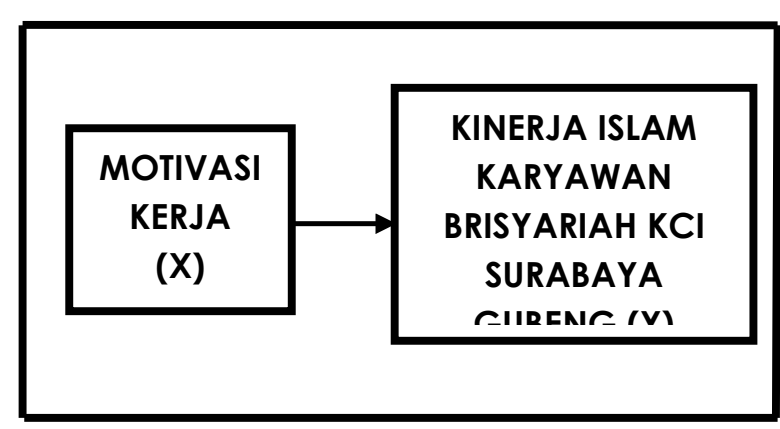

Gambar 1.

Kerangka pemikiran Penelitian

\section{METODE PENELITIAN}

Dalam penelitian ini digunakan variabel penelitian antara lain: Kinerja Islam karyawan sebagai variabel endogen (Y) dan motivasi kerja sebagai variabel eksogen (X). Motivasi kerja terdiri dari tiga indikator: penghargaan terhadap pekerjaan, komunikasi dan informasi yang baik dan jelas, serta kesempatan berpartisipasi. Indikator penghargaan terhadao pekerjaan terdiri dari 11 item pertanyaan, indikator komunikasi dan informasi yang baik dan jelas terdiri dari 10 item pertanyaan, dan indikator kesempatan berpartisipasi terdiri dari 10 item petanyaan. Sedangkan variabel kinerja Islam terdiri dari 10 indikator yang juga digunakan sebagai butir item pertanyaannya melalui pengembangan dengan bantuan operasional sehingga memudahkan penilai kinerja dalam memahami standar penilaian kinerjanya. Indikator tersebut adalah sebagai berikut: Menjalankan pekerjaannya dengan baik dan benar sesuai dengan aturan yang ditentukan perusahaan tempat bekerja; Memiliki kemampuan menguasai pekerjaannya; Niat bekerjanya karena
Allah SWT; Motivasi bekerjanya adalah mencari manfaat dalam hidup; Motivasi bekerjanya adalah mencari ridho Allah SWT; Standar kualitas kerja karyawan unggul dibandingkan dengan standar yang ditetapkan oleh perusahaan tempat bekerja; Menjaga keseimbangan antara mencari harta dengan beribadah saat bekerja; Bekerja keras menyelesaikan pekerjaan dilakukan dengan bersungguhsungguh; Senantiasa bersyukur kepada Allah SWT dan tidak konsumtif saat di tempat kerja; Selalu mengeluarkan ZIS, serta menyantuni anak yatim dan fakir miskin. Keseluruhan jumlah item pertanyaan untuk motivasi kerja adalah 31 item dan untuk kinerja Islam adalah 10 item. Uji reliabilitas menggunakan Cronbach Alpha. Dalam penelitian ini keseluruhan variabel menghasilkan Cronbach Alpha di atas 0,6 sehingga dianggap reliabel. Uji validitas menghasilkan 1 item dalam indikator penghargaan terhadap pekerjaan yaitu item X.7 tidak valid (invalid) sehingga item tersebut harus dihapus agar tidak menghasilkan data eror. Jumlah seluruh item pertanyaan untuk motivasi kerja yang digunakan dalam pengujian selanjutnya adalah setelah dikurangi satu item menjadi 30 item.

Skala pengukuran dalam penelitian ini adalah skala ordinal dengan model skala likert yang menggunakan lima jawaban, yaitu: (SS) Sangat setuju skor 5, (S) Setuju skor 4, (N/CS) Netral atau cukup setuju skor 3, (TS) Tidak setuju skor 2, (STS) Sangat tidak setuju skor 1. Jenis data 
yang digunakan adalah data primer diperoleh melalui daftar pertanyaan kuisioner yang telah diisi oleh responden dan data sekunder sebagai pendukung yaitu berupa dokumen perusahaan yang diantaranya adalah company profile BRISyariah $\mathrm{KCl}$ Surabaya Gubeng, data pendukung seperti jurnal, foto dokumentasi, internet dan literatur yang berhubungan dengan permasalahan yang diteliti.

Subyek atau populasi dalam penelitian ini adalah seluruh karyawan BRISyariah KCl Surabaya Gubeng. Adapun karakteristik sampel yang digunakan adalah karyawan BRISyariah $\mathrm{KCl}$ Gubeng yang memiliki masa kerja minimal tiga bulan. Kriteria karyawan yang telah memiliki masa kerja minimal tiga bulan dianggap telah cukup waktu dalam mengenal lingkungan kerjanya dan menunjukkan kinerjanya Jumlah populasi pada penelitian ini 70 orang.

Teknik pengambilan sampel dalam penelitian ini adalah Non Probability Sampling yaitu teknik pengambilan sampel yang tidak memberikan peluang atau kesempatan yang sama bagi setiap unsur atau anggota populasi untuk dipilih menjadi sampel (Sugiyono, 2012:84). Teknik penentuan sampel yang digunakan adalah dengan teknik sampling purposive yaitu teknik penentuan sampel dengan pertimbangan tertentu sesuai dengan kebutuhan dan tujuan tertentu yang ingin dicapai dalam penelitian (Anshori dan Iswati, 2009:105). Kriteria sampel yang ditentukan adalah karyawan BRISyariah
$\mathrm{KCl}$ Surabaya Gubeng yang sudah bekerja minimal selama tiga bulan sehingga jumlah sampel dalam penelitian ini adalah 44 responden karyawan BRISyariah $\mathrm{KCl}$ Surabaya Gubeng yang memiliki masa kerja minimal 3 bulan.

Jumlah kuisioner yang disebar sebanyak 45 kuisioner dan kembali sebanyak 44 kuisioner karena karyawan yang memenuhi kriteria adalah sebanyak 44 sehingga responsnya sebesar 100\%. Kuisioner yang dianalisis adalah yang layak, artinya semua butir item sudah dijawab oleh responden. Model analisis yang digunakan untuk mengetahui pengaruh adalah regresi sederhana dengan program SPSS. Sedangkan untuk menguji hipotesis yaitu melihat pengaruh signifikan digunakan uji T statistik.

\section{HASIL PENELITIAN DAN PEMBAHASAN}

Pengolahan data dalam pengujian regresi linier sederhana menggunakan software SPSS (Statistical Program Science) versi 16.0 for windows dan diinterpretasikan melalui Tabel 1.

Berdasarkan Tabel 1, dapat diperoleh persamaan regresi linier sederhana yaitu:

$$
Y=1,679+0,546 X
$$

Pada persamaan di atas, dapat diinterpretasikan sebagai berikut:

1. Konstanta pada persamaan regresi sebesar 1,679. Koefisien bertanda positif menunjukkan variabel endogen yang tetap bernilai tinggi (positif) meskipun variabel eksogennya bernilai nol atau konstan. Apabila 
motivasi kerja (X) dianggap bernilai nol atau konstan, maka kinerja Islam (Y) bernilai 1,679 atau dengan kata lain tetap tinggi (positif).

Tabel 1.

Hasil Analisis Regresi Linier Sederhana

kuat antara variabel motivasi kerja (X) terhadap kinerja Islam (Y).

Koefisien determinasi dapat didefinisikan sebagai koefisien yang nilainya didapatkan dari hasil pengujian regresi yang memiliki fungsi untuk mengetahui kemampuan variabel eksogen dalam menjelaskan perubahan variabel endogennya. Apabila nilai koefisien determinasi dalam hal ini ditunjukkan oleh nilai $R$ square atau $\mathrm{R}^{2}$ semakin tinggi maka model analisis regresi semakin baik. Nilai dari R2 ditunjukkan oleh nilai antara 0 sampai 1 . Nilai $R^{2}$ semakin mendekati 1 maka kemampuan

2. Koefisien regresi variabel eksogen yaitu motivasi kerja (X) adalah sebesar 0,546. Sehingga dapat diartikan apabila variabel motivasi kerja (X) ditingkatkan sebesar satusatuan maka kinerja Islam karyawan (Y) meningkat sebesar 0,546 .

$$
\text { Koefisien korelasi dapat }
$$
didefinisikan sebagai suatu besaran yang mengukur seberapa besar tingkat keeratan hubungan antara variabel eksogen $(X)$ yaitu motivasi kerja terhadap variabel endogen yaitu kinerja Islam (Y). Hasil perhitungan koefisien korelasi dapat dilihat pada Tabel 1. Nilai koefisien korelasi ditunjukkan melalui nilai $R$ sebesar 0,848. Interpretasi nilai $R$ sebesar 0,848 menunjukkan apabila skala nilai tertinggi hubungan motivasi kerja dan kinerja Islam karyawan adalah $100 \%$ maka ini membuktikan adanya hubungan yang variabel eksogen dalam menjelasakan variabel endogen dalam model analisis regresi semakin baik.

Pada Tabel 1 menunjukkan nilai koefisien determinasi $\left(R_{2}\right)$ sebesar 0,718 atau $71,8 \%$. Hal ini dapat diartikan bahwa variabel motivasi kerja $(X)$ memiliki proporsi sebesar 0,718 atau $71,8 \%$ dalam pengaruhnya terhadap kinerja Islam (Y) karyawan. Sisa nilai sebesar 0,282 atau $28,2 \%$ dipengaruhi oleh variabel lain diluar penelitian ini.

Selanjutnya

dengan menggunakan uji T statistik, maka dapat diperoleh nilai tingkat signifikansi atau probabilitas sebesar 0,000 . Nilai signifikansi ini lebih kecil dibandingkan nilai $\forall$ sebesar 0,05 . Hasil ini dapat disimpulkan bahwa $\mathrm{H}$ diterima, sehingga dapat diartikan variabel motivasi kerja $(X)$ memiliki pengaruh yang signifikan terhadap kinerja Islam (Y) karyawan. 
Dari hasil penelitian ini dapat disimpulkan bahwa adanya peningkatan kinerja Islam menunjukkan karyawan BRISyariah $\mathrm{KCl}$ Surabaya Gubeng memiliki semangat kerja yang tinggi sehingga mampu menjalankan atau melaksanakan serta menyelesaikan tanggung jawab tugas yang dipercayakan atasan dengan hasil yang baik. Adanya kepentingan secara pribadi maupun kepentingan perusahaan secara interinsik maupun eksterinsik menjadi tujuan yang hendak dicapai sehingga memotivasi karyawan untuk giat dalam bekerja.

Penelitian ini berhasil mendukung penelitian Muafi (2003) dan teori-teori yang dikemukakan oleh tokoh-tokoh dalam ilmu manajemen sumber daya manusia baik konvensional maupun perspektif Islam. Dalam landasan teori telah dijelaskan bahwa Allah tidak akan merubah keadaan hamba-Nya selama mereka tidak berusaha merubah sebabsebab kemunduran mereka. Manusia harus memiliki motivasi untuk berubah ke arah yang lebih baik karena Allah akan menghitung usaha dan amalan umatnya yang berusaha dan beramal. Mereka akan dapat melihat bagaimana hasil usaha dan menerima balasan atas usaha dan amal yang mereka perbuat. Allah akan memberikan nasib baik dan beruntung bagi hamba-Nya yang mau bersungguh-sungguh dalam berusaha.

Dijelaskan pada salah satu ayat AlQur'an surat Al-Rad ayat 11, sebagai berikut:

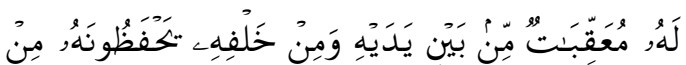

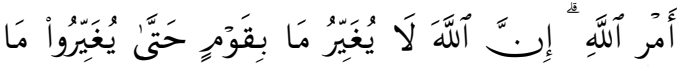

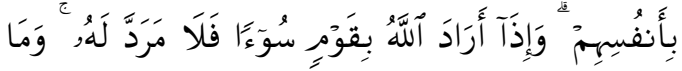

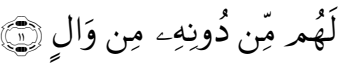

Lahu mu'aqqibā tum mimbaini yadaihi wa min khalfihi yahfaẓu nahu min amrillah. Innallāha lā yugaiyiru mā biqaumin ḥattā yugoyyirū mā bianfusihim. Wa i żā arādallāhu biqaumin sū ān falā maraddalah. Wa mā lahum min dūnihi min wāli.

Artinya: "Bagi manusia ada malaikatmalaikat yang selalu mengikutinya bergiliran, di muka dan di belakangnya, mereka menjaganya atas perintah Allah. Sesungguhnya Allah tidak merubah Keadaan sesuatu kaum sehingga mereka merubah keadaan yang ada pada diri mereka sendiri. dan apabila Allah menghendaki keburukan terhadap sesuatu kaum, Maka tak ada yang dapat menolaknya; dan sekali-kali tak ada pelindung bagi mereka selain Dia." (QS. Al-Rad:11) (Depag Rl, 2002:251)

Allah telah memerintahkan manusia untuk bekerja dan Allah pasti membalas semua yang telah kita kerjakan. Manusia hendaknya bekerja demi mengharap ridha Allah semata sehingga hasil dari pekerjaannya merupakan aktualisasi atas cermin dirinya sebagai hamba Allah. Pahala dan kesuksesan merupakan hasil atas usaha dan kerja keras manusia dalam bekerja 
dengan niat mencari ridha Allah. Manusia akan diberi tahu bagaimana balasan dari usaha dan amalan tersebut. Apabila manusia melakukan dengan kebaikan maka akan dibalas dengan kebaikan. Sebaliknya apabila manusia melakukan dengan keburukan maka akan dibalas dengan keburukan pula.

\section{SIMPULAN}

Berdasarkan hasil analisis tersebut, maka dapat diperoleh kesimpulan hasil formulasi model analisis yaitu:

\section{$Y=1,679+0,546 X$}

Penelitian ini memiliki kesimpulan bahwa motivasi kerja sebagai variabel eksogen (X) memiliki pengaruh terhadap variabel endogen (Y) kinerja Islam karyawan BRISyariah $\mathrm{KCl}$ Surabaya Gubeng dengan pembuktian nilai koefisien regresinya bertanda positif sebesar 0,546 yang artinya apabila motivasi kerja naik sebesar satu-satuan maka kinerja Islam akan meningkat sebesar 0,546. Pengaruh motivasi kerja sangat signifikan terhadap kinerja Islam karyawan BRISyariah $\mathrm{KCl}$ Surabaya Gubeng. Hal ini terlihat dari hasil uji tstatistik menunjukkan hasil nilai signifikan atau probabilitas sebesar 0,000 yaitu lebih kecil dari $\forall$ sebesar 0,05 .

\section{DAFTAR PUSTAKA}

Al-Raysuni, Ahmad. 2006. Imam Al-Shatibi's Theory of the Higher Objectives and Intents of Islamic Law. Kuala Lumpur: The International Institute Of Islamic Thought.
Al-Qur'an dan Terjemahannya. 2002. Al Huda: Mushaf Al-Qur'an Terjemah. Departemen Agama Republik Indonesia. Jakarta: Gema Insani.

Anshori, Muslich \& Sri Iswati. 2009. Metodologi Penelitian Kuantitatif. Surabaya: Pusat Penerbitan Dan Percetakan UNAIR (AUP).

Arcynthia, Lian. 2013. Analisis Pengaruh Kompetensi Terhadap Kinerja Karyawan Pada PT. Bank Bukopin, Tbk Cabang Makassar. Skripsi tidak diterbitkan. Makassar Fakultas Ekonomi Dan Bisnis Universitas Hasanuddin.

Badan Pusat Statistik. Penduduk Indonesia Menurut Provinsi 1971, 1980, 1990, 1995, 2000, dan 2010, (Online), (http://www.bps.go.id, diakses 25 Januari 2014).

Bkkbn. Sudibyo: Kualitas, Kuantitas, dan Dinamika Faktor Penyebab Tingginya Jumlah Penduduk Indonesia, (Online), (http://www.bkkbn.go.id, diakses 24 Januari 2014).

Karim, Adiwarman A. 2008. Ekonomi Mikro Islami. Edisi Ketiga. Jakarta: PT Raja Grafindo Persada.

Muafi. 2003. Pengaruh Motivasi Spiritual Karyawan Terhadap Kinerja Religius: Studi Empiris di Kawasan Industri Rungkut Surabaya (SIER). 
Jurnal Siasat Bisnis. Vol. 1 No. 8: 118.

Rivai, Veithzal. 2009. Islamic Human Capital Dari Teori Ke Praktik Manajemen Sumber Daya Islami. Edisi Pertama. Jakarta: Rajawali Pers.

Robbins, Stephen P. 2003. Organizational Behaviour. Teenth Edition. New Jersey: Prentice.

Shihab, M. Quraish. 2009. Tafsir Al-Mishbah: Pesan, Kesan, dan Keserasian AlQur'an. Vol 1. Edisi Baru. Cetakan Pertama. Jakarta: Lentera Hati. 2009. Tafsir Al-Mishbah: Pesan, Kesan, dan Keserasian Al-Qur'an. Vol 2. Edisi Baru. Cetakan Pertama. Jakarta: Lentera Hati.

2009. Tafsir Al-Mishbah: Pesan, Kesan, dan Keserasian Al-Qur'an. Vol 5. Edisi Baru. Cetakan Pertama. Jakarta: Lentera Hati.

2009. Tafsir Al-Mishbah: Pesan, Kesan, dan Keserasian Al-Qur'an. Vol 6. Edisi Baru. Cetakan Pertama. Jakarta: Lentera Hati.

2009. Tafsir Al-Mishbah: Pesan, Kesan, dan Keserasian Al-Qur'an. Vol 9. Edisi Baru. Cetakan Pertama. Jakarta: Lentera Hati. 2009. Tafsir Al-Mishbah: Pesan, Kesan, dan Keserasian Al-Qur'an.
Vol 14. Edisi Baru. Cetakan Pertama. Jakarta: Lentera Hati.

2009. Tafsir Al-Mishbah: Pesan, Kesan, dan Keserasian Al-Qur'an. Vol 15. Edisi Baru. Cetakan Pertama. Jakarta: Lentera Hati.

Sinambela, Lijian Poltak. 2012. Kinerja Pegawai Teori Pegukuran dan Implikasi. Yogyakarta: Graha IImu.

Sugiyono. 2012. Metode Penelitian Kunatitatif Kualitatif Dan $R$ \& $D$. Cetakan Ke-17. Bandung: Alfabeta.

Tasmara, Toto. 2002. Membudayakan Etos Kerja Islami. Jakarta: Gema Insani.

Tjahjono, Bianawan \& Nur Gunarsih. 2006. Pengaruh Motivasi Kerja Dan Budaya Organisasi Terhadap Kinerja Pegawai di Lingkungan Dinas Bina Marga Propinsi Jawa Tengah. Penelitian Tidak Diterbitkan.

Wibowo. 2013. Manajemen Kinerja. Edisi Ketiga. Cetakan Keenam. Jakarta: Rajawali Pers

Zadjuli, Suroso Imam. 1999. Prinsip-Prinsip Ekonomi Islam. Surabaya: Fakultas Ekonomi Universitas Airlangga. 